\title{
Free-Living Ice-Nucleating Active Bacteria from High Mountain Lake Habitats
}

\author{
MUNTI YUHANA $^{1 *}$ AND KURT HANSELMANN ${ }^{2}$ \\ ${ }^{1}$ Department of Aquaculture, Faculty of Fisheries and Marine Sciences, Institut Pertanian Bogor, \\ Darmaga Campus, Bogor 16680, Indonesia; ${ }^{2}$ Microbial Ecology Group, Institute of Plant Biology, \\ University of Zurich, Switzerland
}

\begin{abstract}
We collected the culturable heterotrophic bacteria from oligotrophic high mountain lake habitats and tested their capability to induce ice formation. Direct plating was carried out using low-nutrient medium at a temperature of between 3 and $4^{\circ} \mathrm{C}$. As many as 84 isolates were recovered from glacial ice and natural biofilm growing on granite rocks surface. Six out of 84 isolates were capable of expressing the ice-nucleation phenotype. After autoclaving the cell suspension at $121^{\circ} \mathrm{C}$ for 15 min, isolate $\mathrm{J} 78$ was still able to retain the ability for ice formation. Heat-stable ice nuclei produced by ice-nucleating active bacteria have potential applications in biotechnology. Characterization of INA bacteria was performed employing live-dead Gram staining and molecular methods. Universal primers for Bacteria (S-D-Bact-0008-b-S-20 and S-D-Bact-1524-a-A-18) were used for PCR to amplify almost the full length of the 16S rRNA genes of selected INA isolates. Restriction fragment length polymorphism analysis resulted in 2 unique patterns, as represented by J43 and J83, respectively. Based on DNA sequencing of 16S rRNA gene, isolate J43 (GeneBank accession no. AJ864852) was closely related to Pseudomonas mephitica (99.2\% sequence similarity) and Janthinobacterium lividum (99\% similarity), whereas isolate J83 (GeneBank accession no. AJ864859) showed 100\% sequence identity to Pseudomonas fluorescens.
\end{abstract}

Key words: high mountain lake habitats, ice nucleation, 16S rRNA gene, free-living bacteria

Various Gram-negative bacteria are capable of catalyzing ice formation at temperatures of -2 to $-12^{\circ} \mathrm{C}$ in nature (Lindow et al. 1982; Hirano et al. 1985). Most of ice-nucleating-active (INA) bacteria are associated with plants (Lindow et al. 1978; Lindermann et al. 1982; Loper and Lindow 1994; Waturangi et al. 2008) or animals (Lee et al. 1995; Worland and Block 1999). Other microorganisms, including several genera of fungi (Pouleur et al. 1992) and lichens (Kieft 1988) have been reported in their ability to induce ice formation. Ice-nucleating active (INA) bacteria have been recovered from various geographical areas, such as Antarctica, temperate, subtropical or tropical regions. INA bacteria, which induce frost damage in various plants, can contribute to a very devastating loss in agricultural crops production (Lindow et al. 1982).

INA bacteria produce outer surface membrane protein that can act as a catalyst for the unusual transition of water from liquid to its solid phase (Gurian-Sherman and Lindow 1993). Droplets of pure water (INA-free water) remain in its liquid state (supercool) up to a temperature of $-40^{\circ} \mathrm{C}$. The higher temperature of ice catalysis conferred by bacterial ice-nuclei makes them useful in ice-nucleation-limited processes such as artificial snow production, the freezing of some food products and possibly in future weather modification schemes (Gurian-Sherman and Lindow 1993).

Up to today, reports on free living INA bacteria recovered from high mountain lake habitats remain limited. Microorganisms that survive and actively grow in these habitats might be good sources of cold-active-proteins, such as ice nucleation active protein, which are catalytically efficient at low temperatures (Gerday et al. 1997). In this study, we report our study on free living INA bacteria recovered from these extreme habitats.

"Corresponding author, Phone: +62-251-8628755, Fax: +62-251-8622941, E-mail: myhn@gmx.ch

\section{MATERIALS AND METHODS}

Samples Collection and Treatments. Samples were collected from the Joeri lakes catchment, located in the southeastern Swiss Alps at an altitude of approximately of $2750 \mathrm{~m}$ a.s.l (Yuhana et al. 2006). Lake water and biofilm samples were aseptically collected during the snow-free season. Subsurface water samples were obtained in sterile glass bottles and patches of biofilm samples were collected from the surface of submerged rocks. Aliquots of 50 and $100 \mu \mathrm{l}$ of water were spread-plated and subcultured onto minimal growth agar medium ( $\mathrm{pH} 7.1$ ), whereas biofilm samples were spread aseptically onto the medium after mechanical disruption of the biofilm with a sterile loop. Growth temperature for all cultures was $4 \pm 1^{\circ} \mathrm{C}$. The minimal growth medium (designated as $\mathrm{MM}$ ) contained the following

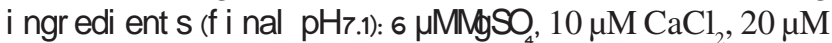
$\mathrm{Na}_{2} \mathrm{CO}_{3}, 14 \mu \mathrm{M} \mathrm{NaNO}_{3}, 10 \mu \mathrm{M} \mathrm{NH}_{4} \mathrm{Cl}, 1.75 \mu \mathrm{M} \mathrm{K}_{2} \mathrm{HPO}_{4}$, $2.7 \mu \mathrm{M}$ EDTANa salt, $10 \mathrm{mg} \mathrm{l}^{-1}$ yeast extract, $10 \mathrm{mg} \mathrm{l}^{-1}$ peptone, $15 \mathrm{~g} \mathrm{l}^{-1}$ washed-bacteriological agar and $1 \mathrm{x}$ trace elements, (added to the autoclaved basal medium). The concentrated trace elements stock solution $(10000 \mathrm{x})$ contained the following: $850 \mu \mathrm{M} \mathrm{ZnSO} \cdot 7 \mathrm{H}_{2} \mathrm{O}, 7100 \mu \mathrm{M} \mathrm{MnCl}_{2} \cdot 4 \mathrm{H}_{2} \mathrm{O}$, $86 \mu \mathrm{M} \mathrm{Co}\left(\mathrm{NO}_{3}\right)_{2} \cdot 6 \mathrm{H}_{2} \mathrm{O}, 1600 \mu \mathrm{M} \mathrm{Na}_{2} \mathrm{MoO}_{4} \cdot 2 \mathrm{H}_{2} \mathrm{O}, 29750 \mu \mathrm{M}$ Citrate $\cdot \mathrm{H}_{2} \mathrm{O}$ and $21480 \mu \mathrm{M}$ Ferric ammonium citrate.

When growth occurred (after 14 to 21 days of incubation in the cold), single colonies of visibly dominant and different colony morphotypes were subcultured onto new minimal medium. Isolates were maintained in $10 \mathrm{x}$ diluted Luria Bertani (LB) agar medium ( $\mathrm{pH}$ 7.2) containing the following ingredients: $0.5 \mathrm{~g} \mathrm{l}^{-1}$ Bacto tryptone, $1.0 \mathrm{~g} \mathrm{l}^{-1}$ yeast extract, $0.5 \mathrm{~g} \mathrm{l}^{-1} \mathrm{NaCl}$ and $15 \mathrm{~g} \mathrm{l}^{-1}$ bacteriological agar.

Cell Morphology and Characterization by Gram Staining. Fluorescent staining was performed to determine the Gram type, characterize cell morphology and to 
distinguish dead cells from living ones. Staining was carried out as described by the manufacturer (Molecular Probes, Inc.) using the Viability Gram Staining Kit (V-7023 Molecular Probes Inc.). The treated samples on slides were observed with a Zeiss Axioplan microscope (Carl Zeiss, Oberkochen Germany) employing 3 different excitation filters (365-395, 450-490 and 546-580 nm) and photographed with an Optronic digital camera.

Ice Nucleation Assay. The ice nucleation capacity of all 84 isolates was tested qualitatively by the tube assay (modified from Hirano et al. 1985). Isolates were grown in $10 \mathrm{ml}$ liquid $\mathrm{MM}$ and incubated at $4^{\circ} \mathrm{C}$ until the stationary phase was reached. Cells were then suspended in $10 \mathrm{ml}$ autoclaved PBS solution $(10 \mathrm{mM}$ potassium phosphatebuffered saline, $\mathrm{pH}$ 7.0) and kept in a cooling-bath at -2 to $-10^{\circ} \mathrm{C}$ for 5 to $10 \mathrm{~min}$. A suspension of $E$. coli cells containing plasmid pJL1703 (Loper and Lindow 1994) was used as a positive control, whereas a cell-free PBS solution served as a negative control. The ice nucleation activity of each INA isolate was observed by droplet-freezing assay and the ice nucleation frequency was calculated by the following formula: $N(t)=[-(\ln f)] / V,($ Vali 1971) where $N(t)$ is the frequency of ice nucleation at $\mathrm{T}$ temperature, $\mathrm{f}$ indicates the proportion of droplets unfrozen and $\mathrm{V}$ is the volume of individual droplets.

Genomic DNA Extraction. Total genomic DNA from pure isolates was extracted with cetyltrimethyl ammonium bromide (CTAB) (modified from Murray and Thompson 1980). This provided a simple, non toxic and inexpensive method and yielded enough DNA template for PCR amplification. After pelleting the cells, extraction buffer $(2 \% \mathrm{w} / \mathrm{v}$ CTAB, $100 \mathrm{mM}$ Tris-Cl pH 8.0, 1.4 M NaCl, 20 mM EDTA) was added and mixed. The solution was incubated at $60^{\circ} \mathrm{C}$ for $30 \mathrm{~min}$ and centrifuged at $12000 \mathrm{xg}\left(4^{\circ} \mathrm{C}\right)$ for $10 \mathrm{~min}$. After transferring the supernatant into a fresh tube, an equal volume of chloroform:isoamyl alcohol (24:1) was added, mixed gently and the solution was centrifugated at $12000 \mathrm{xg}\left(4^{\circ} \mathrm{C}\right)$ for $10 \mathrm{~min}$, these steps were repeated one more time. The resultant supernatant was transferred into a new tube and 1/10 volume equivalent of 7.5 $\mathrm{M}$ ammonium acetate was added. DNA was then collected by precipitation in ethanol. DNA extracts were checked using the following electrophoresis conditions: agarose gel (1\% w/v), [Tris-Acetate-EDTA] (TAE) buffer $0.5 \times$ ( $20 \mathrm{mM}$ Trizma base, $10 \mathrm{mM}$ glacial acetic acid, $0.5 \mathrm{mM}$ EDTA), running time $30 \mathrm{~min}$ at $5 \mathrm{~V} / \mathrm{cm}$. Successful extraction of DNA was verified by staining the gels in a $1 \mu \mathrm{g} \mathrm{ml}^{-1}$ ethidium bromide solution.

16S rRNA Gene Amplification by PCR. Nearly full-length 16S rRNA genes were amplified by PCR using the bacterial primers: S-D-Bact-0008-b-S-20 (5'-AGA GTT TGA TCC TGG CTCAG-3') and S-D-Bact-1524-a-A-18 (5'-AAG GAG GTG ATC CAR CCG-3'). PCR amplification was performed in a $25 \mu$ l reaction volume with a Techne Thermocycler (Techne LTD, Oxford, UK). Each reaction mixture contained (final concentration) Taq buffer (1x) (Sigma), 1.5-2.0 mM MgCl 2 , $0.1 \mathrm{mg} \mathrm{ml}^{-1}$ DNase-free Bovine Serum Albumin (Amersham, Pharmacia Biotech Inc.), $0.2 \mathrm{mM}$ dNTPs, $200 \mathrm{nM}$ of forward and reverse primer, respectively, $40 \mathrm{U}$ Taq Polymerase (Sigma), $\mathrm{ddH}_{2} \mathrm{O}$ and approximately of 20-100 ng of template DNA. The following touch-down PCR program was used: initial denaturation at $94^{\circ} \mathrm{C}$ for $2 \mathrm{~min} ; 20$ cycles of $94^{\circ} \mathrm{C}$ for
$20 \mathrm{sec}, 63^{\circ} \mathrm{C}$ for $30 \mathrm{sec}$ with lowering temperature by $0.5^{\circ} \mathrm{C}$ in every cycle, $72^{\circ} \mathrm{C}$ for $80 \mathrm{sec}$ with increasing duration by $1 \mathrm{sec}$ in every cycle; another 20 cycles of $94^{\circ} \mathrm{C}$ for $20 \mathrm{sec}$, $53^{\circ} \mathrm{C}$ for $30 \mathrm{sec}, 72^{\circ} \mathrm{C}$ for $100 \mathrm{sec}$ with increasing period by 1 sec every cycle; followed by a final extension step at $72^{\circ} \mathrm{C}$ for $10 \mathrm{~min}$. PCR products were analyzed by electrophoresis in $1 \% \mathrm{w} / \mathrm{v}$ agarose gels in $0.5 \mathrm{x}$ TAE running buffer, stained with ethidium bromide $\left(1 \mu \mathrm{g} \mathrm{ml}^{-1}\right)$ and photographed under UV. For RFLP analysis, $8 \mu \mathrm{l}$ PCR products were doubledigested with $1 \mathrm{U}$ restriction enzyme HinfI (5'-G/ANTC) and Hae III (5'-GG/CC) in a total reaction volume of $10 \mu \mathrm{l}$.

Sequencing. The PCR products of the 16S rRNA genes from different RLFP patterns were purified through microcon centrifugal filter devices (Microcon YM 100, Millipore, Bedford, Mass., USA). Nearly full-length 16S rRNA genes were bidirectionally sequenced with a DNA sequencer (ABI Prism 377), using ABI Prism ${ }^{\circledR}$ Big Dye $^{\mathrm{TM}}$ v2.0 (Applied Biosystems) as described by the manufacturer with the following 6 primers: S-D-Bact-0008-b-S-20 (5'-AGA GTT TGA TCC TGG CTC AG-3'), S-*-Univ-0519-a-A-18 (5'-GWATTA CCGCGGCKGCTG-3'), S-*-Univ-0519-a-S-18 (5'-CAGCMG CCGCGGTAATWC-3'), S-D-Bact-1099-b-S-16 (5'-GYAACG AGC GCAACC C-3'), S-D-Bact-1099-b-A-16 (5'-GGG TTG CGC TCG TTR C-3') and S-D-Bact-1524-a-A-18 (5'-AAG GAG GTG ATC CAR CCG-3'). For a $10 \mu$ l-single PCR reaction, 5 to 20 ng DNA template, $3 \mu \mathrm{l}$ Big Dye (Applied Biosystems) and $3 \mu \mathrm{l}$ of $1.5 \mu \mathrm{M}$ primer were used. After the sequencing PCR, the products were purified with Sephadex G-50 (Amersham, Pharmacia Biotech $\mathrm{AB}$ ) and loaded onto a sequencing machine (ABI Prism 377 DNA Sequencer). The BLAST search tool available from NCBI (http://www.ncbi.nlm.nih.gov/blast) was used to list the closest neighbors of the sequences.

Phylogenetic Tree Construction. The phylogenetic tree was analysed online using the Phylip Interface, available at the ribosomal database project (http://rdp8.cme.msu.edu/ html/analyses.html). Sequence data was imported and aligned to their closest neighbors by an automated alignment. The distance matrix was calculated by maximum likelihood method and a phylogenetic tree was constructed based on neighbor-joining analysis.

\section{RESULTS}

Eighty-four isolates were recovered from lake water, glacier and biofilm growing on granite rocks surface. Generally they are cream-pigmented morphotypes and some of them were capable of producing water-soluble yellowgreenish fluorescent pigments. Test tube assay showed that 6 out of 84 isolates were capable of catalyzing the ice nucleation in the tubes at temperatures between -2 to $-5^{\circ} \mathrm{C}$. Fluorescent microscopy determination after live-dead Gram staining, showed that all of the 6 INA isolates were Gram negative and rod shaped (Fig 1).

After autoclaving the cell suspension at $121^{\circ} \mathrm{C}$ for 15 minutes, isolate $\mathrm{J} 78$ still showed its ability to initiate the ice formation at lower temperatures, ranging from -8 to $-10^{\circ} \mathrm{C}$. Other INA isolates (J43, J71, J77, J83 and J84) and autoclavedpositive control, were no longer capable of catalyzing ice formation even at lower temperatures (Fig 2). 


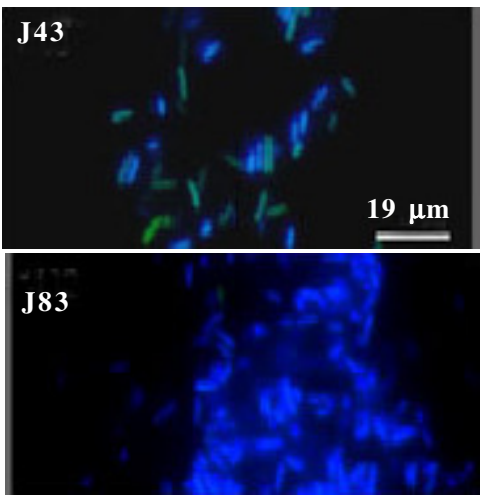

Fig 1 Fluorescent micrographs of isolate $\mathrm{J} 43$ and $\mathrm{J} 83$. Live cells fluoresce blue, whereas dead cells fluoresce green. Both isolates were Gram negative.

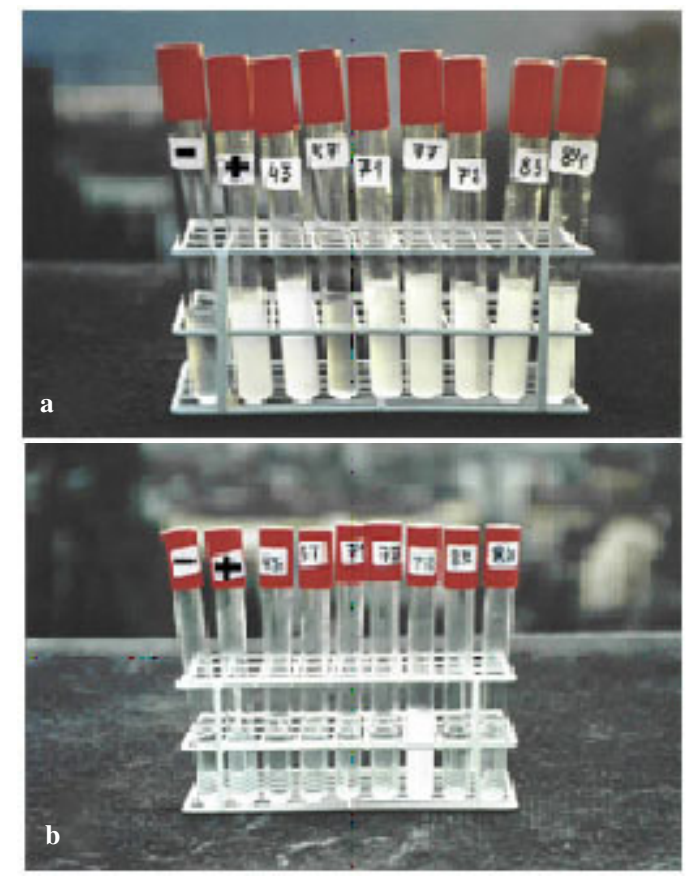

Fig 2 Ice nucleating assay tubes. (a) Assay carried out before autoclaving the cell suspension at the temperature ranging from from -2 to $-5^{\circ} \mathrm{C}$. Assay showed ice nucleation capability of isolate J43, J71, J77, J78, J83, and J84. J57 represents a non ice-nucleatingactive isolate, remaining unfrozen after 30 minutes incubation at temperatures ranging from -8 to $-10^{\circ} \mathrm{C}$. Cell-free PBS solution (-) serves as a negative control, while cell suspension of $E$. coli containing plasmid pJL1703 was used as a positive control; (b) Assay carried out after autoclaving the cell suspension. Suspension of the isolate J78 remaining capable of inducing the ice nucleation at lower temperatures ranging from -8 to $-10^{\circ} \mathrm{C}$.

The highest ice nucleation activity among INA isolates was shown by $\mathrm{J} 84$ with frequency of 60 nuclei $\mathrm{ml}^{-1}$ and the lowest was indicated by isolate $\mathrm{J} 71$ ( 32 nuclei $\left.\mathrm{ml}^{-1}\right)$. Isolates $\mathrm{J} 43, \mathrm{~J} 77$ and $\mathrm{J} 83$ had the same ice nucleation frequency of 38 nuclei $\mathrm{ml}^{-1}$ and isolate $\mathrm{J} 78$ was 46 nuclei $\mathrm{ml}^{-1}$ (Table 1 ). The temperature of the assay was warm $\left(-2^{\circ} \mathrm{C}\right)$. Ice nucleation activity of isolate $\mathbf{J} 78$ after autoclaving was 46 nuclei $\mathrm{ml}^{-1}$ at $-8^{\circ} \mathrm{C}$.

PCR amplifications of the 16S rRNA gene of selected INA isolates yielded products of approximately $1500 \mathrm{bp}$. By using double restriction with HinfI and HaeIII, two different RFLP patterns were obtained. J83 has a unique pattern, whereas J43 shows corresponding band patterns with
Table 1 Ice nucleation activity of free living INA bacteria from high mountain lake habitats

\begin{tabular}{lcc}
\hline Isolate & $\begin{array}{c}\text { No of frozen droplets/ } \\
\text { total droplets }\end{array}$ & $\mathrm{N}(\mathrm{t})$ (at temperature) \\
\hline $\mathrm{J} 43$ & $17 / 20$ & 38 nuclei $/ \mathrm{ml}\left(-2^{\circ} \mathrm{C}\right)$ \\
$\mathrm{J} 71$ & $16 / 20$ & 32 nuclei $/ \mathrm{ml}\left(-2^{\circ} \mathrm{C}\right)$ \\
$\mathrm{J} 77$ & $17 / 20$ & 38 nuclei $/ \mathrm{ml}\left(-2^{\circ} \mathrm{C}\right)$ \\
$\mathrm{J} 78$ & $18 / 20$ & 46 nuclei $/ \mathrm{ml}\left(-2^{\circ} \mathrm{C}\right)$ \\
$\mathrm{J} 83$ & $17 / 20$ & 38 nuclei $/ \mathrm{ml}\left(-2^{\circ} \mathrm{C}\right)$ \\
$\mathrm{J} 84$ & $19 / 20$ & 60 nuclei $/ \mathrm{ml}\left(-2^{\circ} \mathrm{C}\right)$ \\
J78 (after autoclaving) & $18 / 20$ & 47 nuclei $/ \mathrm{ml}\left(-8^{\circ} \mathrm{C}\right)$ \\
\hline
\end{tabular}

$\mathrm{N}(\mathrm{t})$, ice nucleation activity; where $\mathrm{N}$, frequency of ice nucleation at temperature $\mathrm{t}$.

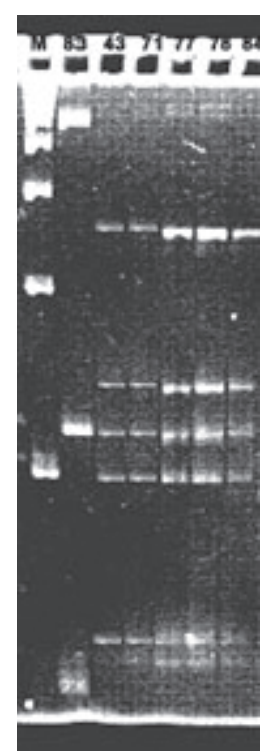

Fig 3 RFLP patterns of 16S-rRNA genes from the INA isolates. Lane 1, molecular marker $100 \mathrm{bp}$ ladder (Pharmacia, Biotech); Lane 2-7, J83, J43, J71, J77, J78, and J84. Running conditions on Spreadex EL-800 gel (Elchrom Sci.): $70 \mathrm{Vcm}^{-2}$ for $90 \mathrm{~min}$, running temperature $55^{\circ} \mathrm{C}$ in $30 \mathrm{mM}$ TAE buffer.

isolates J43, J71, J77, J78 and J84 (Fig 3). 16S rRNA genes of isolates $\mathrm{J} 83$ and $\mathrm{J} 43$ (as a representative of other 5 INA isolates) were selected for sequencing.

The DNA sequence of isolate J43 (1484 bp) showed 99.2\% similarity to Pseudomonas mephitica or Janthinobacterium lividum. The nucleotides have been submitted to the GenBank with accession no. AJ864852. DNA sequence of isolate J83 (1491 bp) showed $100 \%$ similarity to P. fluorescens CCM 2115 and has been submitted with accession no. AJ864859.

\section{DISCUSSION}

All INA isolates from high mountain lake habitats showed ice nucleation activity at temperatures warmer than $-5^{\circ} \mathrm{C}$. Similar results were shown in a previous study (Kieft 1988) of INA associated with lichens isolated from high mountain habitats. His study showed that several epilithic lichen samples of the genera Rhizoplaca, Xanthoparmelia and Xanthoria expressed ice nucleation activity at temperature as warm as $-2.3^{\circ} \mathrm{C}$. According to the ice nucleation proteins classification described by Turner $e t$ al. (1990), all of our INA isolates are characterized as class A, which showed ice nucleation activity between temperature range of -2 to $-5^{\circ} \mathrm{C}$. Waturangi et al. (2008) reported that 
tropical INA bacterial isolates showed ice nucleation activity at cooler temperature of $-8^{\circ} \mathrm{C}$ and categorized as class B. At this temperature, the ice nucleation activity values of tropical

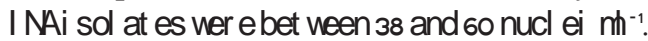

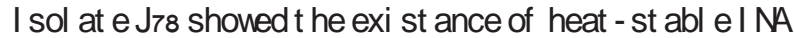

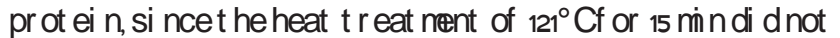

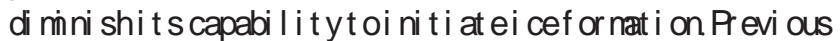

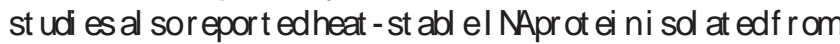
a lichen, Rizoplaca chrysoleuca (Kieft 1988) and from Fusarium (Pouleur et al. 1992). Kieft (1988) reported that control cell suspension (no heat treatment) and $10 \mathrm{~min}$ treatment at temperatures of 40 to $70^{\circ} \mathrm{C}$, showed the ice nucleation activity at temperatures between -2.3 to $-3.3^{\circ} \mathrm{C}$, whereas the ice nucleation activity at a lower temperature of $-14.6^{\circ} \mathrm{C}$ was detected after cell suspension exposed by heat treatment at temperature range of 80 to $95^{\circ} \mathrm{C}$. Our isolate $\mathrm{J} 78$ showed its ice nucleation ability at warmer temperatures than that of INA expressed by R. chrysoleuca, i.e. at temperatures ranging from -8 to $-10^{\circ} \mathrm{C}$. This might indicate a more stable INA protein structure present in this isolate, however, further studies are required to determine the uniqueness of the J78 INA protein.

Based on their DNA sequences, our INA isolates phylogenetically fall into the $\hat{a}$ - and $\tilde{a}$-subgroups of Proteobacteria (Fig 4). Isolate J83, which is closest related to $P$. fluorescens strain IAM12022, belonging to the gammasubdivison. P. fluorescens has been reported to belong to the bacteria which are able to catalyze ice formation (Lee $e t$ al. 1995) while isolate $\mathrm{J} 43$ falls into the $\hat{a}$ - subdivison. This isolate is closely related to P. mephitica ATCC 33665T or J. lividum DSM 1522T. To our knowledge, there are no other reports on the ability of the bacteria belonging to $P$. mephitica or J. lividum in catalyzing the ice formation.

Bacteria which are able to catalyze water crystallization may have an advantage over those which cannot. Those which can will be able to survive in frozen environments through slow cellular dehydration (Baertlein et al. 1992). This is a very important property for microorganisms to survive in this cold and extreme habitat. Ice formation on the outside of the cell allows water molecules to move from the cytoplasm across the cell membrane to join crystals of pure water nucleated extracellularly. This increases the osmotic potential inside the cells, thereby preventing freezing and cell damage by internal ice crystals. The ice nucleation process allows for ordered propagation of ice throughout the cell rather than a rapid freezing, which can result in membrane rupture and cell death (Baertlein et al. 1992). Since this ability was only found in 6 out of the 84 isolates, we must assume that other bacteria use different strategies to survive periods of freezing, for instance by producing anti-freeze proteins (Feller et al. 1996) or other osmolytes.

\section{ACKNOWLEDGEMENTS}

This work was supported by an annual grant from the Microbial Ecology Group, Insitute of Plant Biology, University of Zurich. Authors would like to thank to Steven Lindow, UCLA-Berkeley, USA for positive control sample of E. coli (pJL1703).

\section{REFERENCES}

Baertlein DA, Lindow SE, Panopaulos NJ, Lee SP, Mindrinos MN, Chen THH. 1992. Expression of bacterial ice nucleation gene in plants. Plant Physiol 100:1730-1736.

Feller G, Narinx E, Arpigny JL, Aittaleb M, Baise E, Genicot S, Gerday C. 1996. Enzymes from psychrophilic organisms. FEMS Microbiol Rev 18:189-202.

Gerday C, Aittaleb M, Arpigny JL, Baise E, Chessa JP, Garsoux G, Petrescu I, Feller G. 1997. Psychrophilic enzymes: a thermodynamic challenge. Biochim Biophys Acta Prot Struct Mol Enzymol 1342:119-131.

Gurian-Sherman D, Lindow SE. 1993. Bacterial ice nucleation: significance and molecular basis. FASEB J 7:1338-1343.

Hirano SS, Baker LT, Christen DU. 1985. Ice nucleation of individual leaves in relation to population sizes of ice nucleation active bacteria and frost injury. Plant Physiol 77:259-265.

Kieft TL. 1988. Ice nucleation activity in Lichens. Appl Environ Microbiol 54:1678-1681.

Lee MR, Lee RE, Strong-Gunderson JM, Minges SR. 1995. Isolation of ice-nucleating active bacteria from the freeze-tolerant frog, Rana sylvatica. Cryobiology 32:358-365.

Lindermann J, Constantinidou HA, Barchet WR, Upper CD. 1982. Plants as sources of airborne bacteria, including ice nucleation bacteria. Appl Environ Microbiol 44:1059-1063.

Lindow SE, Arny DC, Upper CD. 1978. Distribution of ice nucleationactive bacteria on plants in nature. Appl Environ Microbiol 36:831-838.

Lindow SE, Arny DC, Upper CD. 1982. Bacterial ice-nucleation: a factor in frost injury to plants. Plant Physiol 70:1084-1089.

Loper JE, Lindow SE. 1994. A biological sensor for iron available to bacteria in their habitats on plant surfaces. Appl Environ Microbiol 60:1934-1941.

Murray MG, Thompson WF. 1980. Rapid isolation of high molecular weight plant DNA. Nucl Acids Res 8:4321-4325. 